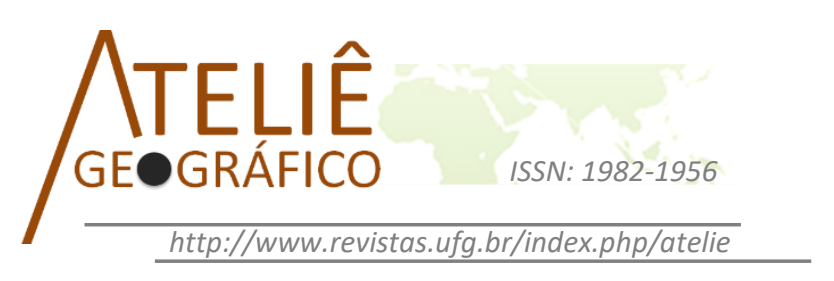

\title{
Questões ambientais nos livros didáticos de geografia das escolas municipais e estaduais de Jataí (GO)
}

\author{
Environmental issues of geography didactic books at Jatai's \\ municipal and state school (GO)
}

\section{Questions environnementales dans l'enseignement de géographie dans les écoles publiques de Jataí (GO)}

\author{
Andréa Pereira Pinto \\ Universidade Federal de Goiás - Regional Jataí \\ andreageog@hotmail.com \\ Zilda de Fátima Mariano \\ Universidade Federal de Goiás - Regional Jataí \\ zildadefatimamariano@gmail.com
}

\begin{abstract}
Resumo
O livro didático tem sido um instrumento empregado de maneira quase unânime, mas nem sempre é aproveitado de forma criteriosa no processo de ensino-aprendizagem. O objetivo da pesquisa foi analisar as questões ambientais sobre a Educação Ambiental (EA), as mudanças climáticas, o desmatamento, a poluição do ar e da água nos livros didáticos do $6^{\circ}$ ano das escolas municipais e estaduais de Jataí (GO). A metodologia consistiu em Silva (2004) para analisar os conteúdos ambientais nos livros didáticos, considerando os conteúdos abordados, a concepção de natureza, a consistência e as lacunas. Como resultado, o tema EA não é tratado em nenhum dos livros. O livro do município expressa uma visão ambiental nos alunos ao contemplar os temas propostos para a pesquisa. Já no livro do estado, percebe-se que as questões ambientais são discutidas com quantidade insuficiente de atividades, figuras, gráficos e textos contextualizados sobre os impactos ambientais e que estimulem a conscientização dos alunos. Dessa forma, os livros dão apoio para que o professor possa trabalhar suas aulas de forma interativa com os alunos, visando o aprendizado deles, levando-os a uma visão crítica das questões ambientais, considerando as sugestões dadas para abordá-las com maior aprofundamento.
\end{abstract}

Palavras-chave: livro didático, ensino de geografia, Jataí (GO). 


\begin{abstract}
The textbook has been an instrument used almost unanimously, but it is not always used in a judicious way in the teaching-learning process. The objective of the research was to analyze the environmental issues on Environmental Education (EA), climate change, deforestation, air and water pollution in the textbooks of the 6th grade of the municipal and state schools of Jataí (GO). The methodology consisted of Silva (2004) to analyze the environmental contents in the textbooks, considering the contents covered, the conception of nature, the consistency and the gaps. As a result, the EA theme is not covered in any of the books. The book of the municipality expresses an environmental vision in the students when contemplating the themes proposed for the research. In the state textbook, we can see that environmental issues are discussed with insufficient amounts of activities, figures, graphs and texts contextualized on environmental impacts and that stimulate students' awareness. In this way, the books provide support so that the teacher can work his classes in an interactive way with the students, aiming at their learning, taking them to a critical view of environmental issues, considering the suggestions given to approach them with more depth.
\end{abstract}

Keywords: textbook, geography education, Jataí (GO).

\begin{abstract}
Résumée
Le manuel a été un instrument utilisé presque à l'unanimité, mais il n'est pas toujours utilisé de manière judicieuse dans le processus d'enseignement-apprentissage. L'objectif de la recherche était d'analyser les questions environnementales sur l'éducation environnementale (EE), les changements climatiques, la déforestation, la pollution de l'air et de l'eau dans les manuels scolaires de la 6e année des écoles publiques et municipales de Jataí (GO). La méthodologie a consisté à Silva (2004) pour analyser le contenu de l'environnement dans les manuels scolaires, compte tenu du contenu couvert, le concept de la nature, la cohérence et les lacunes. Par conséquent, le thème EA n'est couvert dans aucun livre. Le livre de la municipalité exprime une vision environnementale chez les étudiants lors de la réflexion sur les thèmes proposés pour la recherche. Déjà dans l'état du livre, il est clair que les questions environnementales sont discutées avec des activités insuffisantes, des chiffres, des graphiques et des textes contextualisées sur les impacts environnementaux et à améliorer leur prise de conscience des élèves. Ainsi, les livres apportent un soutien afin que l'enseignant puisse travailler de manière interactive vos classes avec les élèves, dans le but de leur apprentissage, les menant à une vision critique des questions environnementales, en tenant compte des suggestions données pour les traiter avec une plus grande profondeur.
\end{abstract}

Mots-clés: manuel scolaire, enseignement de la géographie, Jataí (GO).

\title{
Introdução
}

Atualmente, vários problemas ambientais têm sido detectados, como desmatamento, erosões de solo, problemas hídricos, entre outros. Dentre esses problemas, que se desenvolvem em escalas global, regional e local, a ação antrópica é a principal responsável. Nas últimas décadas, diante das novas tecnologias, a apropriação 
do espaço torna-se cada vez mais rápida e predatória, acarretando diversas degradações sobre a natureza.

Os problemas ambientais têm sido muito discutidos nesta primeira década do século XXI. No Brasil, esse debate foi iniciado tardiamente, por vários motivos, dentre os quais se inclui o período da ditadura, nas décadas de 1960 até 1980, auge das discussões ambientais no mundo. Segundo Dias (2004), o Brasil, imerso no regime ditatorial, na "contramão" da tendência internacional de preocupação com o ambiente, mostrava ao mundo o Projeto Carajás e a Usina Hidrelétrica de Tucuruí, iniciativas de alto potencial de degradação ambiental, o que foi confirmado décadas depois.

De acordo com Carvalho (2003, p. 253 apud Ferreira et al., 2012, p. 253), os problemas ambientais não são recentes, pois encontra histórico desde os filósofos gregos clássicos até os pré-socráticos. $\mathrm{O}$ autor ainda enfatiza que "[...] o que difere a atual questão ambiental, das preocupações passadas, é o avanço da apropriação do 'homem' dos recursos naturais em escala global [...]".

A discussão ambiental no ensino de Geografia é de suma importância, por permitir que os alunos se conscientizem para o seu papel na preservação do ambiente. Segundo Desiderio (2012, p. 1), essas discussões "pretendem 'sensibilizar', 'conscientizar' ou informar os sujeitos sobre maneiras ecológica ou ambientalmente corretas de agir, consumir e pensar o ambiental”.

As questões ambientais, como por exemplo, a Educação Ambiental (EA), as mudanças climáticas, a poluição do ar e da água e o desmatamento são temas que devem ser trabalhados com os alunos, não só pela contribuição para o desenvolvimento do pensamento crítico do aluno, mas devido às recomendações produzidas por conferências e reuniões ambientais como o Rio-92, que indicam soluções para a crise ambiental planetária por meio de uma série de normas e atitudes consideradas corretas. Dentre as recomendações geradas pelas conferências, segundo destacam-se, "“...] a necessidade do enfoque interdisciplinar na educação, a reorientação da mesma para o desenvolvimento sustentável e a promoção da conscientização popular através de informações sobre o meio ambiente" (DESIDERIO, 2012, p. 9).

A principal ferramenta para o ensino na sala de aula é o livro didático (FRISON et al., 2009). Dessa forma, evidencia-se a importância de discussões a respeito de livros que atendam às demandas das questões ambientais.

No início dos anos 90, o Ministério da Educação (MEC) deu os primeiros passos para participar mais direta e sistematicamente das discussões sobre a qualidade do livro escolar através do Programa Nacional do Livro Didático (PNLD). Porém, visando somente à avaliação do livro didático, o MEC apresentou um projeto pedagógico difundido por meio dos Parâmetros Curriculares Nacionais (PCN) e dos Guias do livro didático, a partir de 1993, criando uma comissão de especialistas, encarregada de duas 
tarefas principais: avaliar a qualidade dos livros mais solicitados ao Ministério e estabelecer critérios gerais para a avaliação das novas aquisições.

Para avaliar um livro didático, vários critérios devem ser contemplados, dentre os quais, segundo Spósito (2006), os principais referem-se à coerência teóricometodológica, à presença de erros conceituais ou de informação e à presença de preconceito ou indução a ele. Para Silva (2004), ao se estudar a Geografia, é preciso que sejam considerados o aluno e a sociedade em que ele vive. Os temas não podem ser soltos, partes do espaço, não pode ser feita apenas descrição dos lugares especificamente nos tópicos referentes à natureza. É importante promover a interação entre os elementos da natureza, compreendendo que os processos naturais têm relação uns com os outros.

Dessa forma, partindo da premissa de que o livro didático é uma ferramenta utilizada pelos professores, o objetivo deste trabalho foi analisar os conteúdos ambientais Educação Ambiental (EA), mudanças climáticas, poluição do ar e da água e desmatamento, contidos nos livros didáticos de Geografia de 2014 da rede pública de ensino municipal e estadual de Jataí (GO). O presente artigo tem origem na dissertação de mestrado "Questões ambientais no ensino de Geografia nas escolas públicas em JATAÍ (GO)", defendida junto ao Programa de Pós-Graduação em Geografia da Universidade Federal de Goiás (UFG), Regional Jataí. A geografia e o livro didático no PCN.

Criado em 1998 pelo Ministério de Educação (MEC), o PCN vem com o objetivo de nortear os professores em relação aos conteúdos a serem ministrados no ensino fundamental, os quais são organizados por eixos temáticos que abrangem temas e itens, sendo que cada eixo temático guarda em si temas que permitirão ao professor ampla reflexão sobre os diferentes enfoques que poderão ser feitos pela Geografia.

As orientações constantes no PCN para o ensino fundamental são divididas em quatro ciclos compostos por duas séries; sendo o $1^{\circ}$ ciclo com as $1^{\mathrm{a}}$ e $2^{\mathrm{a}}$ séries, o $2^{\mathrm{o}}$ ciclo com as $3^{\mathrm{a}}$ e $4^{\mathrm{a}}$ séries, o $3^{\mathrm{o}}$ ciclo com as $5^{\mathrm{a}}$ e $6^{\mathrm{a}}$ séries e, por fim, o $4^{\mathrm{o}}$ ciclo, com as $7^{\mathrm{a}}$ e $8^{\mathrm{a}}$ séries. Atualmente, com a nova divisão do ensino, a $6^{\mathrm{a}}$ e $7^{\mathrm{a}}$ séries equivalem aos atuais $5^{\circ}$ e $6^{\circ}$ anos, respectivamente. É por esse motivo que essa pesquisa enfoca nos $3^{\circ}$ e $4^{\circ}$ ciclos do PCN de Geografia, pois versam sobre as questões ambientais (BRASIL, 1998).

Ao tratar o tema meio ambiente, o PCN aponta que esse é um assunto interdisciplinar, que abarca uma compreensão diferenciada de cada área da ciência, não sendo possível um olhar de apenas uma área de estudo.

A proposta de temas transversais dentro da Geografia, envolvendo a natureza, é encontrada como a questão ambiental, a pluriculturalidade brasileira, relações de trabalho e de consumo, entre outros. As questões ambientais, na Geografia, podem ser inseridas nos mais diversos assuntos que abrangem a disciplina, como colocado pelo próprio PCN (1998, p. 46):

[...] o estudo mais detalhado das grandes questões do Meio Ambiente (poluição, desmatamento, limites para uso dos recursos 
naturais, sustentabilidade, desperdício), permite o trabalho com a espacialização dos fenômenos geográficos por meio da cartografia. Permite, também, o trabalho com as estatísticas, base de dados, leitura e interpretação de gráficos que são importantes nos estudos comparativos, nas simulações e na ideia inicial sobre planejamento que os alunos podem ter. Ainda como conteúdo procedimental, trabalhar com a formulação de hipóteses, produção de gráficos e mapas, coleta, organização e interpretação de dados estatísticos, prática da argumentação etc.

Desta forma, a EA é encontrada no PCN de Geografia no terceiro e quarto ciclos do ensino fundamental: no terceiro ciclo, as questões ambientais são encontradas no eixo 2, intitulado "o estudo da natureza e sua importância para o homem”; já no quarto ciclo, é encontrada no eixo 3, "modernização, modo de vida e a problemática ambiental".

No terceiro ciclo, são abordadas as questões do papel da natureza e sua relação com a ação dos indivíduos, e tem como objetivos propostos pelo PCN (1998, p. 53), envolvendo as questões ambientais:

a) reconhecer que a sociedade e a natureza possuem princípios e leis próprios e que o espaço geográfico resulta das interações entre elas, historicamente definidas;

b) perceber, na paisagem local e no lugar em que vivem, as diferentes manifestações da natureza, sua apropriação e transformação pela ação da coletividade, de seu grupo social;

c) reconhecer e comparar a presença da natureza, expressa na paisagem local, com as manifestações da natureza presentes em outras paisagens;

d) reconhecer a importância de uma atitude responsável de cuidado com o meio em que vivem, evitando o desperdício e percebendo os cuidados que se devem ter na preservação e na conservação da natureza.

Os objetivos envolvendo as questões ambientais estão contidos no eixo 2, pois é nessa fase que o aluno já possui raciocínios mais abstratos e complexos, cabendo ao professor realizar a mediação do aluno para a compreensão da dinâmica entre a sociedade e natureza, sendo que o professor deve buscar diversos recursos a fim de motivar os alunos nesses temas.

Tratando-se dos temas específicos da Geografia, BRASIL, (1998, p. 62) coloca que não se deve esquecer que é necessário fazer a interação entre os elementos da natureza, como exemplo, "relacionar o clima e a vegetação, os solos e o relevo, ou ainda como clima, solos e relevo se inter-relacionam", tornando-se, assim, capazes de instigar o aluno a uma reflexão crítica sobre a relação homem e meio. 
A abordagem no ensino da questão ambiental leva em consideração a transversalidade do tema e também a interdisciplinaridade presente no mesmo, como coloca o PCN (1998, p. 46):

A compreensão das questões ambientais pressupõe um trabalho interdisciplinar. A análise de problemas ambientais envolve questões políticas, históricas, econômicas, ecológicas, geográficas, enfim, envolve processos variados, portanto, não seria possível compreendê-los e explicá-los pelo olhar de uma única ciência. Como o objeto de estudo da Geografia, no entanto, refere-se às interações entre a sociedade e a natureza, um grande leque de temáticas de meio ambiente está necessariamente dentro do seu estudo.

Portanto, é possível relacionar os problemas ambientais com diferentes áreas de ensino e o PCN deixa aberto um diálogo aos professores quando da elaboração de projetos envolvendo os alunos, em que esses problemas podem ser minimizados em escala local.

\section{Livros didáticos de Geografia considerando o PNLD}

De acordo com Höfling (2000), o PNLD é um programa criado pelo Estado com a função da distribuição gratuita de livro didático. No que se refere ao fornecimento do material didático-pedagógico, o principal objetivo é:

[...] subsidiar o trabalho pedagógico dos professores por meio da distribuição de coleções de livros didáticos aos alunos da educação básica. Após a avaliação das obras, o Ministério da Educação (MEC) publica o Guia de Livros Didáticos com resenhas das coleções consideradas aprovadas. O guia é encaminhado às escolas, que escolhem, entre os títulos disponíveis, aqueles que melhor atendem ao seu projeto político pedagógico (BRASIL, 2013).

Para a seleção dos livros didáticos, o PNLD (2013, p. 7) coloca que "o livro didático precisa ser adequado ao projeto político-pedagógico e à realidade sociocultural da sua escola, ao aluno e ao professor". Desta forma, faz-se necessário conhecer e analisar as características, a estrutura e as possibilidades de trabalho da realidade escolar do local para a seleção dos livros didáticos, para que, assim, o mesmo seja um facilitador e um recurso com uma abordagem e método precisos para a sala de aula, de forma que interaja com o Programa Político Pedagógico (PPP) da escola.

Em torno do PNLD e do livro didático existem várias discussões que envolvem a ideologia do livro, o histórico, o uso do livro didático, seu desenvolvimento etc. Outra discussão presente nas escolas, nas universidades e em diferentes divulgações acadêmicas 
é a escolha do livro didático, que faz parte da política pública do Brasil para educação, envolvendo, portanto, política e economia (KANASHIRO, 2008; ALVES, 2011).

No âmbito político, observa-se, na visão de Kanashiro (2008, p. 8), que "a decisão em torno da política do livro didático se encerra no domínio de técnicos e assessores burocratas governamentais, distante da realidade escolar". Essa tarefa devia contar com a participação de outros atores sociais, como igrejas, cientistas, sindicatos e, principalmente, professores e alunos.

Sobre a dimensão econômica, o livro didático é uma mercadoria, um grande negócio que faz parte da lógica de produção do sistema capitalista, cuja finalidade é o lucro. Na briga pelo comércio, estão as editoras, que vão disputar através da estratégia da melhor estética e apresentação dos livros, deixando em segundo plano, muitas vezes, o conteúdo (KANASHIRO, 2008). A esse respeito, Mochiute (2009, p. 1) afirma que:

A escolha de livros didáticos pelos professores da rede pública de ensino é limitada pela capacidade de publicidade das editoras. Só as grandes conseguem enviar livros para os professores avaliarem. Assim, a escolha é limitada por princípios de mercado, não pedagógicos. A pluralidade é comprometida pela alta concentração do mercado.

Além dos aspectos políticos e econômicos, devem ser considerados os aspectos culturais e sociais, pois, segundo Alves (2011, p. 10):

[...] não podemos esquecer as diversas interferências que ocorrem no seu processo de produção, circulação e consumo. É preciso refletir sobre a sua finalidade educativa sem perder de vista os interesses econômicos que norteiam decisões políticas e financeiras. Perceber a posição complexa assumida pelo livro didático como instrumento de política educacional, mas também produto da indústria cultural, termo este utilizado aqui na sua abrangência mais genérica.

Percebe-se então que a discussão do livro didático não envolve somente o uso em sala de aula, vai mais além; há questões ideológicas que, com certeza, estarão presentes nas atividades em sala de aula. E, neste momento, cabe ao professor, que não participou do processo de produção do livro, intermediar as informações prontas e acabadas.

As questões ideológicas, políticas, econômicas e sociais não são as únicas reflexões do professor; na prática escolar são inúmeras as realidades e experiências vividas pelo educador, dentre as quais podemos destacar desde a falta de materiais pela escola até a falta de interesse para a aprendizagem por parte dos alunos. Desta forma, visando ao aprendizado além da utilização dos livros didáticos, os quais têm o objetivo de nortear os professores em relação aos conteúdos a serem ministrados, há uma 
necessidade de o professor buscar novas referências e atualidades que estejam no contexto dos alunos.

O PNLD ressalta a importância do livro didático como recurso pedagógico ao mesmo tempo em que enfatiza que ele não deve ser o único recurso a ser utilizado pelo professor em sala de aula, e sim um dos meios para auxiliar no processo de ensino. Com isso, faz-se necessário desenvolver metodologias e procurar recursos para se chegar a um aprendizado significativo dos alunos, buscando sempre a atenção deles para o ensino.

Contudo, o livro didático, às vezes, é desvalorizado e torna-se descartável e sem valor quando está fora de seu contexto original. Entretanto, concordamos com Fernandes (2004, p. 537), quando afirma que "para uma pessoa que valoriza a educação, que tem sua vida profissional ligada ao magistério, o livro didático ganha em sua memória outra coloração". Percebe-se que o professor que "está professor" e não o que "é professor" acaba por embarcar e explorar o livro didático superficialmente, não efetivando assim o aprendizado dos alunos, o que também acaba por fazer com que eles percam esse interesse em buscar informações.

Porém, segundo Vesentini, (1989), o professor pode e deve encarar o manual, o livro didático, não como definidor de todo o seu curso, de todas as suas aulas, mas fundamentalmente como um instrumento que está a seu serviço, a serviço de seus objetivos e propostas de trabalho.

O livro didático é um instrumento norteador, que proporciona conhecimentos, que faz parte da prática de sala de aula e é norteado por parâmetros de ensino, com objetivo de facilitar o aprendizado.

Os conhecimentos geográficos podem ser adquiridos de diferentes formas dentro da relação docente, alunos e os recursos de ensino, e, dentro dessa relação, o livro didático:

[...] tem grande importância, pois está presente na maioria das salas de aula. O docente não deve considerar os alunos como depósitos de informações e o livro adotado não pode ser o definidor de todo o processo de ensino aprendizagem. Professores e alunos é que são os sujeitos, capazes de problematizar os conteúdos, trazendo a abordagem dos mesmos para a realidade local (MACEDO; CUNHA, 2012, p. 173).

No ensino de Geografia, o livro didático é peça fundamental no processo ensino-aprendizagem, e, em sala de aula, muitas vezes é considerado como única fonte de saber, ou, em outras palavras, "é o lugar do saber definido, pronto, acabado, correto e, dessa forma, fonte única de referência e contrapartida dos erros das experiências de vida" (VESENTINI, 2007, p. 166). 
Quando o professor coloca o livro como único norteador do processo de ensino, proporciona um ambiente fechado para diálogo e sem debate dos conteúdos nele apresentados, muito menos estimula a participação ativa dos alunos no processo ensinoaprendizagem e, principalmente, deixando de proporcionar que o ensino geográfico seja aplicado no cotidiano do aluno. Pelo contrário, o livro didático tem papel "orientador, que auxilia o diálogo do aluno com a realidade” (VESENTINI, 2007, p. 173).

O livro didático, ao ser utilizado pelo professor de forma ideal e como um instrumento de apoio para os conhecimentos de Geografia, ele se torna:

[...] um material de apoio fundamental no desenvolvimento do trabalho docente e no processo de aprendizagem dos educandos. Por essa razão, as obras destinadas ao ensino e à aprendizagem da Geografia devem conter textos, atividades e ilustrações que possibilitem ao educando o domínio dos conceitos espaciais e da sua representação (BRASIL, 2013, p. 42).

Mas, para que essa finalidade do livro seja plenamente alcançada, é necessário que os conceitos e informações estimulem o desenvolvimento das capacidades básicas do pensamento crítico do aluno.

\section{Procedimentos metodológicos Área de estudo}

A cidade de Jataí está compreendida entre as coordenadas 8018000 e 8028000 Sul, 420000 e 4290000 Oeste. O município está inserido na microrregião Sudoeste de Goiás, com área total de $7.174 \mathrm{~km}^{2}$, população de 88.006 habitantes e densidade de 12,23 hab $/ \mathrm{km}^{2}$ (IBGE, 2010). Jataí conta com 22 escolas públicas de ensino fundamental, sendo 12 estaduais e 10 municipais (TABELA 01 e MAPA 01). A pesquisa foi realizada nas escolas: Antônio Tosta, David Ferreira, Marcondes de Godoy e Emília Ferreira de Carvalho.

Tabela 01. Relação das escolas municipais e estaduais de Jataí (GO)

\begin{tabular}{lll}
\hline $\mathbf{N}^{\circ}$ & Nome da escola & Tipo \\
\hline $\mathbf{0 1}$ & Antônio Tosta de Carvalho & Municipal \\
02 & Auta de Souza & Municipal \\
$\mathbf{0 3}$ & David Ferreira & Municipal \\
04 & Rio Paraíso II & Municipal \\
05 & Romualda Barros & Municipal \\
06 & Clobertino Neves & Municipal \\
07 & Flávio Vilela & Municipal \\
08 & Professor João Justino de Oliveira (CAIC) & Municipal \\
\hline
\end{tabular}




\begin{tabular}{lll}
\hline $\mathbf{N}^{\circ}$ & Nome da escola & Tipo \\
\hline 09 & Luziano Dias de Freitas & Municipal \\
10 & Professora Isabel Franco de Moraes e Silva & Municipal \\
11 & Nestório Ribeiro & Estadual \\
12 & Samuel Graham & Estadual \\
13 & João Roberto Moreira & Estadual \\
14 & José Feliciano Ferreira & Estadual \\
$\mathbf{1 5}$ & Marcondes de Godoy & Estadual \\
16 & José Manoel Vilela & Estadual \\
17 & Serafim de Carvalho & Estadual \\
18 & Polivalente Dante Mosconi & Estadual \\
19 & Alcântara de Carvalho & Estadual \\
$\mathbf{2 0}$ & Emília Ferreira de Carvalho & Estadual \\
21 & Frei Domingos & Estadual \\
22 & Washington Barros Franca & Estadual \\
\hline
\end{tabular}

Fonte: Pinto (2014).

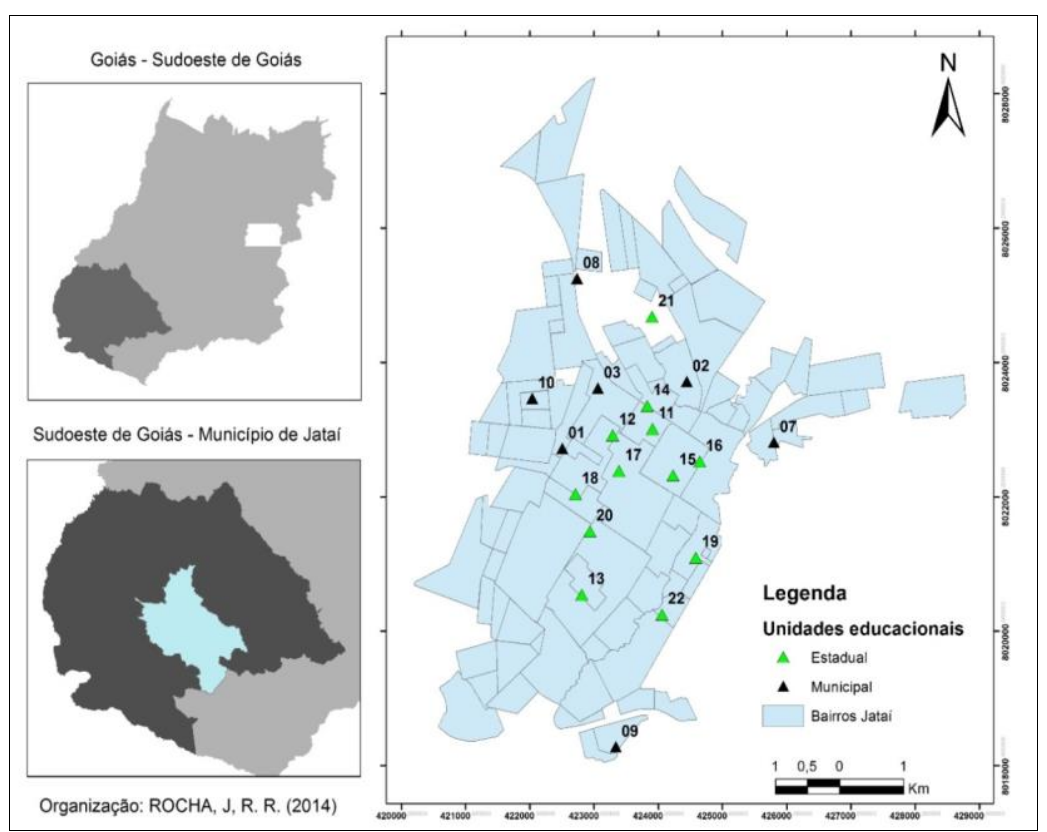

Figura 01. Localização da área de estudo.

Organização: Pinto (2014). 


\section{Procedimento metodológico para seleção das escolas pilotos para aplicação da pesquisa}

Visto que o município de Jataí possui 22 escolas, foi necessária uma seleção por amostragem, isso devido à dificuldade de aplicar os questionários em todas. Desta forma, utilizou-se um sorteio simples como critério de seleção do número de escolas, no qual foram sorteadas duas escolas municipais e duas estaduais, com base na metodologia de Lakatos e Marconi (1992).

As escolas selecionadas foram: Marcondes de Godoy, localizada na rua Rui Barbosa, 640 - Centro, Escola Emília Ferreira de Carvalho, situada na rua Dom Pedro II, 2111 - Jardim Rio Claro, Escola Municipal Antônio Tosta, na rua Minas Gerais, 1800 Setor Planalto e Escola Municipal Davi Ferreira, na rua Sebastião R. Cintra, 176, Setor Antena.

\section{Procedimento metodológico de análise do livro didático}

A base metodológica de análise do livro didático utilizada foi de Silva (2004, p. 09), a qual define uma ficha de avaliação que contempla os seguintes pontos:

a) Conteúdos abordados, relato sobre o conteúdo proposto em cada livro, tomando como referência o sumário, os capítulos e subcapítulos;

b) Concepção de natureza, análise da concepção da natureza presente em cada livro, avaliando os temas propostos nos objetivos da pesquisa;

c) Consistência em relação aos temas abordados (questões ambientais) nos livros, verificando a abordagem;

d) Avaliar a presença de lacunas na construção dos conceitos (questões ambientais) e clareza e adequação ao nível do ensino nesta pesquisa.

A pesquisa utilizou a análise dos livros didáticos de Geografia do ensino fundamental do $6^{\circ}$ ano, nas escolas municipais e estaduais, adaptando em relação às questões ambientais e à identificação das lacunas presentes nos livros didáticos e sugestões para os conteúdos relacionados à questão ambiental. Para análise das questões ambientais nos livros didáticos foram considerados o conceito de EA, mudanças climáticas, poluição do ar, poluição da água e desmatamento.

Segundo Dias (2004, p. 523), EA é um processo permanente no qual os indivíduos e a comunidade tomam consciência do seu meio ambiente e adquirem conhecimentos, valores, habilidades, experiências e determinação que os tornem aptos a agir e resolver problemas ambientais, presentes e futuros.

O Painel Intergovernamental sobre Mudanças Climáticas (IPCC) (2007 apud FARIA e HADDAD, 2013, p. 1) define mudança climática como a: 
[...] variação estatisticamente significante em um parâmetro climático médio ou sua variabilidade, persistindo um período extenso (tipicamente décadas ou por mais tempo). A mudança climática pode ser devido a processos naturais ou forças externas ou devido a mudanças persistentes causadas pela ação do homem na composição da atmosfera ou do uso da terra.

A poluição pode ser compreendida, de forma simplificada, como a introdução no ambiente de energia e/ou matéria sólida líquida e/ou gasosas, em quantidades maiores do que a capacidade ambiental de absorção e depuração daquelas, acarretando mudanças nas características físicas, químicas ou biológicas do meio e danos à saúde humana e aos demais organismos. De acordo com a Resolução CONAMA n 003, de 28 de junho de 1990, entende-se como poluente atmosférico:

[...] qualquer forma de matéria ou energia com intensidade e em quantidade, concentração, tempo ou características em desacordo com os níveis estabelecidos, e que tornem ou possam tornar o ar:

I - impróprio, nocivo ou ofensivo à saúde;

II - inconveniente ao bem-estar público;

III - danoso aos materiais, à fauna e flora.

IV - prejudicial à segurança, ao uso e gozo da propriedade e às atividades normais da comunidade (CONAMA, 1990, on-line).

O desmatamento é uma questão ambiental que a partir de sua prática pode desencadear vários impactos ambientais, sendo considerado pelo Ibama (2015, on-line) como:

[...] a operação que objetiva a supressão total da vegetação nativa de determinada área para o uso alternativo do solo. [...] Reforçamos o entendimento de que qualquer descaracterização que venha a suprimir toda vegetação nativa de uma determinada área deve ser interpretada como desmatamento.

O Ibama (2015, on-line) entende como área selecionada para uso alternativo do solo "aquelas destinadas à implantação de projetos de colonização de assentamento de população; agropecuários; industriais; florestais; de geração e transmissão de energia; de mineração; e de transporte".

Os livros didáticos adotados nas escolas do município e do estado são diferentes. No município adota-se o Para Vivermos Juntos, de Fernando dos Santos Sampaio; no estado, o Expedições Geográficas, de Melhem Adas e Sérgio Adas (FIGURAS 2A e 2B). 

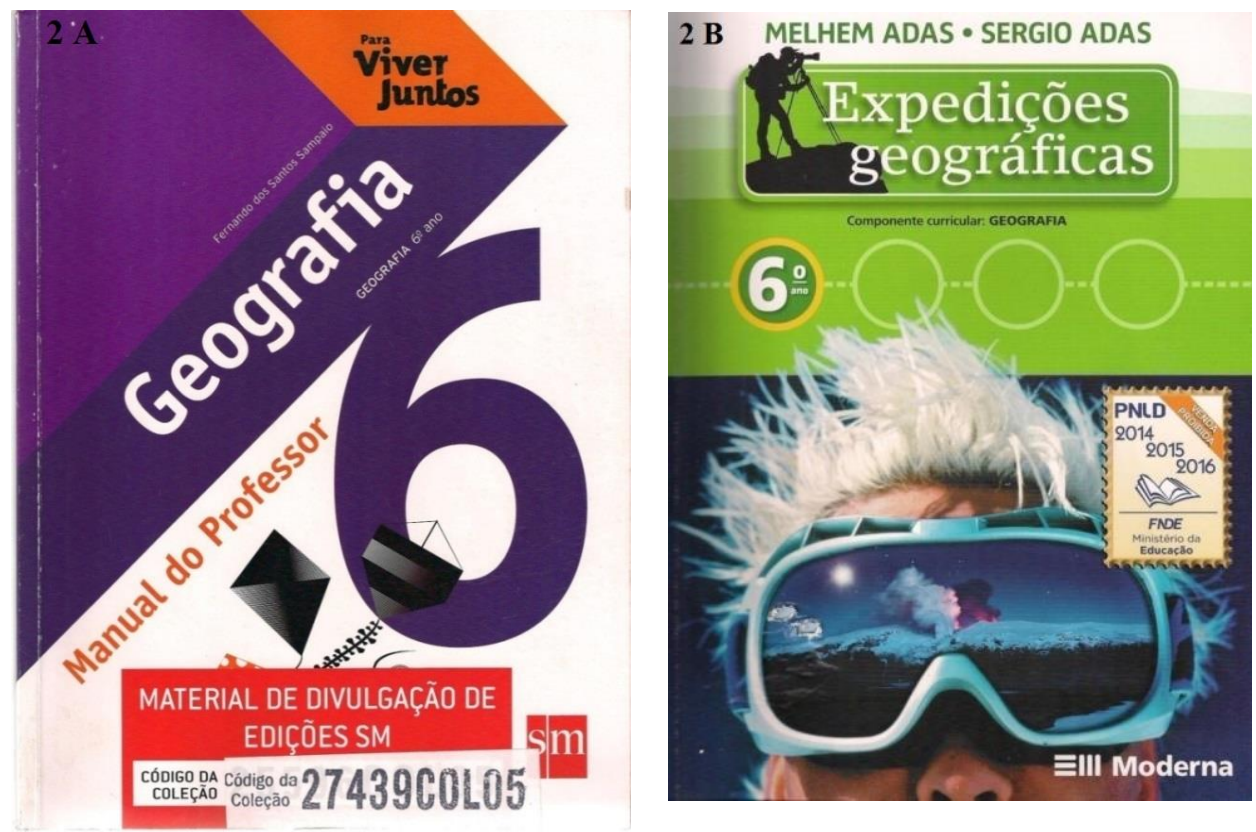

Figuras 02A e 02B. Capas dos livros didáticos dos $6^{\circ}$ anos, das redes de ensino municipal (2A) e estadual (2B).

Fonte: Sampaio (2012) e Adas e Adas (2011).

\section{Resultados e discussões}

Questões ambientais abordadas no livro didático Para Viver Juntos, adotado pela rede de ensino municipal de Jataí

A partir da apresentação do material adotado pelo município e pelo estado, observou-se que os livros apresentam os temas sugeridos para pesquisa. O livro adotado pela rede municipal trabalha as mudanças climáticas, a poluição do ar, da água e o desmatamento com textos, atividades, ilustrações, sendo que os temas são colocados de forma mais abrangente para o aluno. É possível perceber uma interação maior entre os conteúdos e a forma de apresentá-los, facilitando, assim, a aprendizagem.

No livro adotado pela rede estadual, o conteúdo é abordado de forma mais superficial e não é possível perceber a intenção do autor de conscientizar os educandos, fazendo com que seja subentendido que os alunos já tenham conhecimento dos assuntos trabalhados. 
Em Para Viver Juntos, o conceito de educação ambiental não é apresentado; porém, o livro retrata temas ligados à educação ambiental, como a coleta seletiva e a reciclagem.

No contexto da educação ambiental, o assunto coleta seletiva e reciclagem (FIGURA 03) estão no Capítulo 05, sobre a crosta terrestre, que é um tema relevante, visto que cada vez mais se produz resíduo e as alternativas para a minimização do problema parte da educação, procurando incentivar a diminuição do consumo.

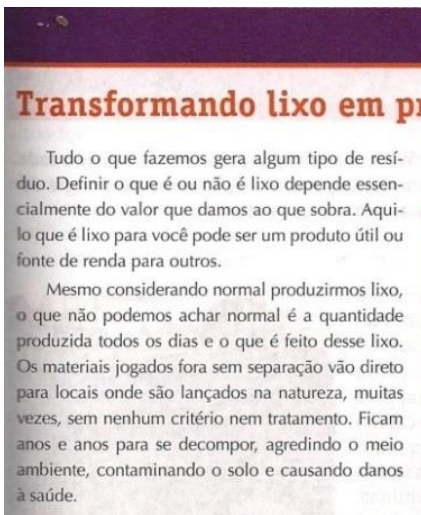

\section{0 que fazer?}

Procurar alternativas para o grande volume de lixo é uma necessidade urgente e diz respeito a todos. Uma das soluçōes para esse problema está na mudança de atitudes, na prática de novos hábitos de consumo consciente e na forma de jogar fora aquilo que é considerado lixo.

Em muitas cidades já existe a preocupação com o destino dos resíduos sólidos - em aterros sanitários, que não causam danos ao ambiente e à saúde. Algumas - bem poucas, na verdade - também se preocupam com a recuperação e a reciclagem dos materiais.

Além de diminuir o volume de lixo, quando reciclamos estamos ajudando a economizar recursos naturais, a aumentar o número de empregos entre catadores, sucateiros, donos de depósitos, etc. A reciclagem depende da coleta seletiva, por isso é importante colocar os materiais no lugar certo.

\section{Mundo aberto}

\section{produtos e empregos}

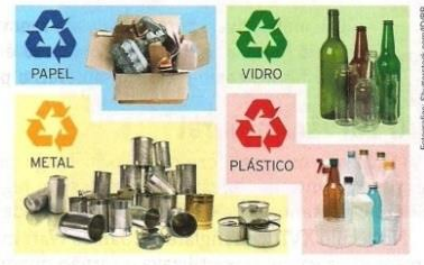

\section{A coleta seletiva}

Nesse sistema, são separados os materiais não recicláveis dos recicláveis, que deixam de ser lixo e se tornam novamente produtos.

A reciclagem é fonte de geração de emprego para milhares de pessoas em todo o pais. Muitas dessas pessoas são mulheres, que encontram na reciclagem uma oportunidade de trabalho e renda que não tinham antes.

Diversas organizações dão apoio a esses trabalhadores. Uma das primeiras foi o Projeto das Unidades de Reciclagem de Porto Alegre, implantado em 1989. Na maioria das unidades predominam as mulheres, em gera responsáveis pela separação do material, enquanto os homens realizam os trabalhos de carregamento e prensagem.

Também existem organizaçōes que incentivam o trabalho artesanal com material de reciclagem. Nesse caso também as mulheres são maioria. 0 artesanato dá valores e funçôes a objetos que seriam descartados.

Os homens e as mulheres envolvidos com a reciclagem realizam um trabalho de grande valor para a sociedade e precisam receber cada vez mais o apoio do governo e o respeito de todas as pessoas.

\section{Atividades}

1. Junte todo lixo que você acumula durante um dia. Deixe esses resíduos separados e, no fim do dia, avalie a quantidade acumulada e o que está sendo descartado. 0 que você conclui? Provavelmente os alunos perceberão que è muito grandé a quantidade de lixo que as pessoas pro-

Figura 03. Atividades propostas sobre o lixo.

Fonte: Sampaio (2012, p. 93). 
A reciclagem foi abordada no texto Transformando lixo em produto e emprego. Nota-se que a atividade proposta permite ao educando uma reflexão sobre a sua prática, no que consiste ao lixo acumulado em casa, demonstrando de forma consciente a questão.

Além da atividade presente sobre a coleta seletiva, sugere-se que os docentes façam uma pesquisa sobre a coleta seletiva na cidade e a quantidade de resíduos produzidos pela população e, para o debate em sala após a pesquisa, a busca por alternativas para solucionar os possíveis problemas identificados, recomendando-se como material complementar o documentário "História do lixo de Jataí".

A importância da reciclagem pode ser o foco dado ao resíduo quando se passa a olhá-lo com um grande potencial de matéria-prima. Segundo Rego, et al (2002, p. 8), "a maior parte do lixo produzido é orgânico, constituído por restos de alimentos, cascas de frutas e de verduras". E a partir do momento que se enxerga o lixo como um produto a ser reciclado, ele "gera postos de trabalho e, consequentemente, renda, sendo preciso mudar a cultura em relação ao lixo, responsabilizando quem produz o mesmo" (PINTO, 2007, p. 45).

Sobre o desmatamento, o livro didático retrata-o, no Capítulo 9: A Biosfera, apresentando a problemática do desmatamento em áreas de nascentes, o assoreamento de rios e a impermeabilização do solo, que colaboram para redução da reposição dos aquíferos.

O livro também une o conceito de desmatamento com o de impacto ambiental, para responsabilizar o homem por alterações no meio ambiente, afirmando que:

Em muitos países, existe legislação que prevê o estudo de possíveis impactos ambientais antes da intervenção humana no meio ambiente - por exemplo, antes da construção de uma estrada. Esses estudos, associados a outras medidas, procuram evitar grandes e destrutivas alterações no ambiente natural (SAMPAIO, 2012, p. 207).

Apesar de mencionar a legislação ambiental, o assunto desmatamento é exposto brevemente. Além do mais, não são compartilhadas atividades e/ou textos que estimulem a conscientização dos alunos sobre o tema, somente uma imagem sobre o desmatamento da Floresta Amazônica (FIGURA 04). 


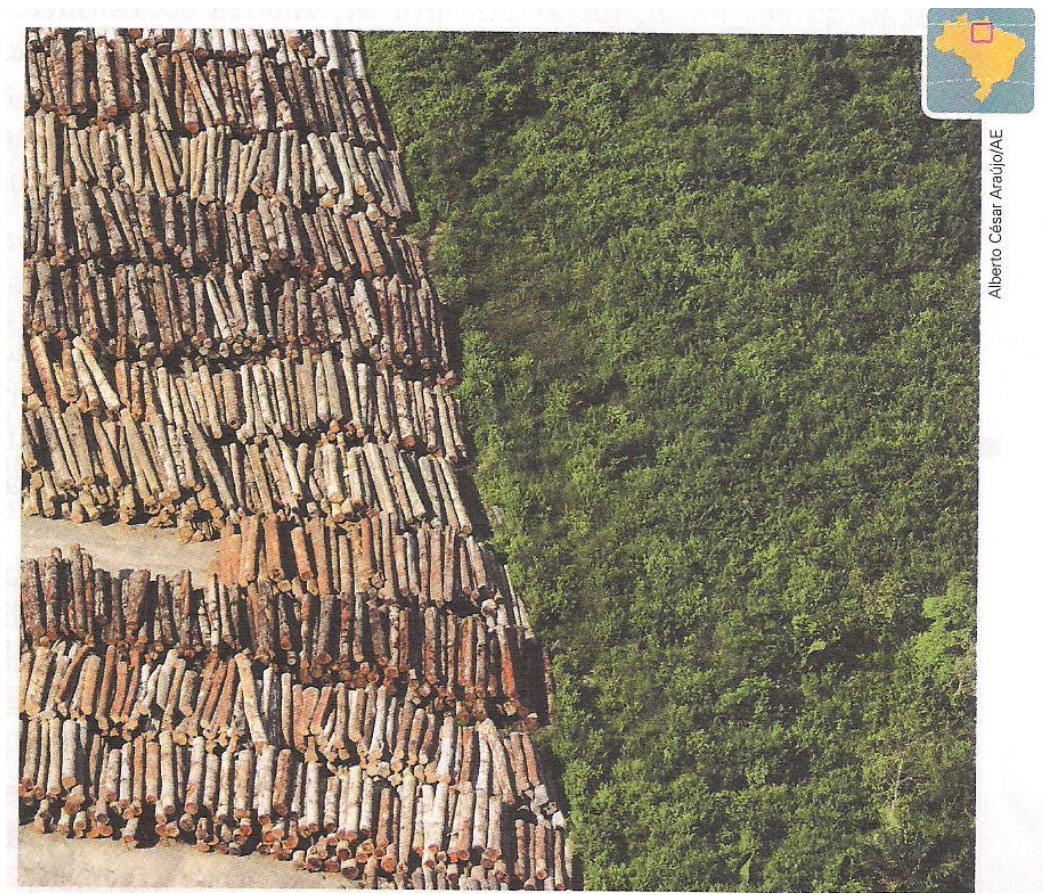

Figura 04. Madeiras retiradas da Floresta Amazônica em Santarém (PA) Fonte: Sampaio, (2012, p.193).

Sobre as mudanças climáticas, o Capítulo 08: A atmosfera terrestre, discorre com profundidade acerca do tema por meio do artigo As mudanças climáticas globais $e$ as alterações na biosfera global (FIGURA 05). Mas, antes do texto, o autor orienta os alunos a interpretarem a imagem e analisarem a sua ligação com as mudanças climáticas. Em seguida, há três questões na seção "Olho no texto" como atividade para os alunos. 


\section{Lendo Geografia}

Antes de ler

- Com base no título e na fonte do texto, levante hipóteses sobre os temas que serão abordados.

- De que modo os ursos-polares representados na imagem podem ilustrar as informações contidas no título?

\section{As mudanças climáticas globais e as alterações na biosfera global}

[...] Vários episódios relacionam as mudanças climáticas globais com alterações na biodiversidade. No Ártico, a temperatura subiu $5{ }^{\circ} \mathrm{C}$ nos últimos cem anos e desde 1978 suas geleiras diminuem a uma taxa de $3 \%$ por década. Os modelos climáticos preveem que, em 2080, não haverá mais gelo durante os meses de verão, levando os ursos-polares à extinção por fome. As geleiras alpinas perderam metade de seu volume desde 1850, e espécies características das baixas montanhas suíças migraram para as altas montanhas. Os estoques do salmão do Atlântico Norte serão destruídos quando a temperatura regional do oceano aumentar $6{ }^{\circ} \mathrm{C}$ da média histórica. A diminuição no estoque de peixes levou à morte centenas de milhares de aves marinhas nas costas da Califórnia.

[...]

O declínio de populações de anfíbios por todo o globo surge como um dos mais dramáticos eventos de destruição maciça da fauna [...]. O pequeno sapo-dourado (Bufo peri- glenes), exclusivo das montanhas de neblina da Costa Rica, foi declarado extinto. Reproduzindo-se somente em uma específica janela climática, ocorreu que $30 \mathrm{mil}$ indivíduos não se reproduziram devido à ausência de poças ocasionada pela estação muito seca de 1987 [...].

Jô Enéas Salati, Ângelo Augusto dos Santos e Carlos Nobre. As mudanças climáticas globais e seus efeitos nos ecossistemas brasileiros. Disponivel em: <http://www.comciencia.br/ reportagens/clima/clima14.htm>. Acesso em: 11 jul. 2011.

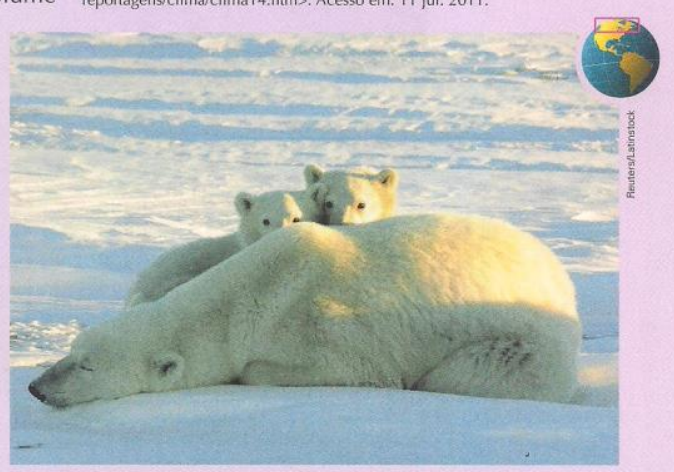

Ursos-polares no Canadá, em 2011.

Degundo 0 artigo, a temperatura no Ártico teria subido $5^{\circ} \mathrm{C}$ nos úitimos cem anos, e desde 1978 suas geleiras estariam diminuindo a uma taxa de $3 \%$ por década. As geleiras alpinas teriam perdido metade de seu volume desde 1850, e os estoques de salmäo do Atlantico Norte seriam destruidos quando a temperatura regional do

1. O texto acima é um artigo publicado em uma revista eletrônica. Quais são os principais dados que ele apresenta? oceano aumentasse $6^{\circ} \mathrm{C}$ em relação à média histórica. 30 mil indivíduos de sapo-dourado, en

2. Com base nas informações do texto, discuta com seus colegas a importância da introdução de políticas de redução da emissão de poluentes na atmosfera. Resposta pessoal. É importante que o aluno perceba que o aquecimento global está levando à destruiçăo hábitats e espécies animais e vegetais.

3. Formem grupos e façam uma pesquisa em livros, jornais, revistas e na internet para saber que outros animais correm risco de extinção em razão do aumento da temperatura global. Façam um mural na sala de aula e convidem outros colegas da escola para conhecer o trabalho. Se for preciso, peçam ajuda ao professor de Ciências durante a pesquisa. Resposta pessoal. As espécies mais ameaçadas pelo aumento das temperaturas globais săo as que dependem de condiçōes especificas de temperatura para sobreviver ou de condiçōes ambientais que podem ser alteradas pela elevação da temperatura. Alguns exemplos de seres vivos afetados pelo aquecimento global, além dos ursos-polares, são os corais, os plânctons e os pinguins.

Figura 05. Atividade do livro didático com o tema mudanças climáticas Fonte: Sampaio (2012, p.193). 
No Capítulo 07: A atmosfera terrestre, o tema poluição da água foi abordado no livro por meio na poluição e degradação das águas oceânicas (FIGURA 06). São apontados os principais causadores da poluição dos oceanos, que são os resíduos industriais, pesticidas, fertilizantes, esgoto doméstico e petróleo (proveniente de vazamentos de barcos, de naufrágios de petroleiros e de escapes de plataformas petrolíferas e oleodutos).

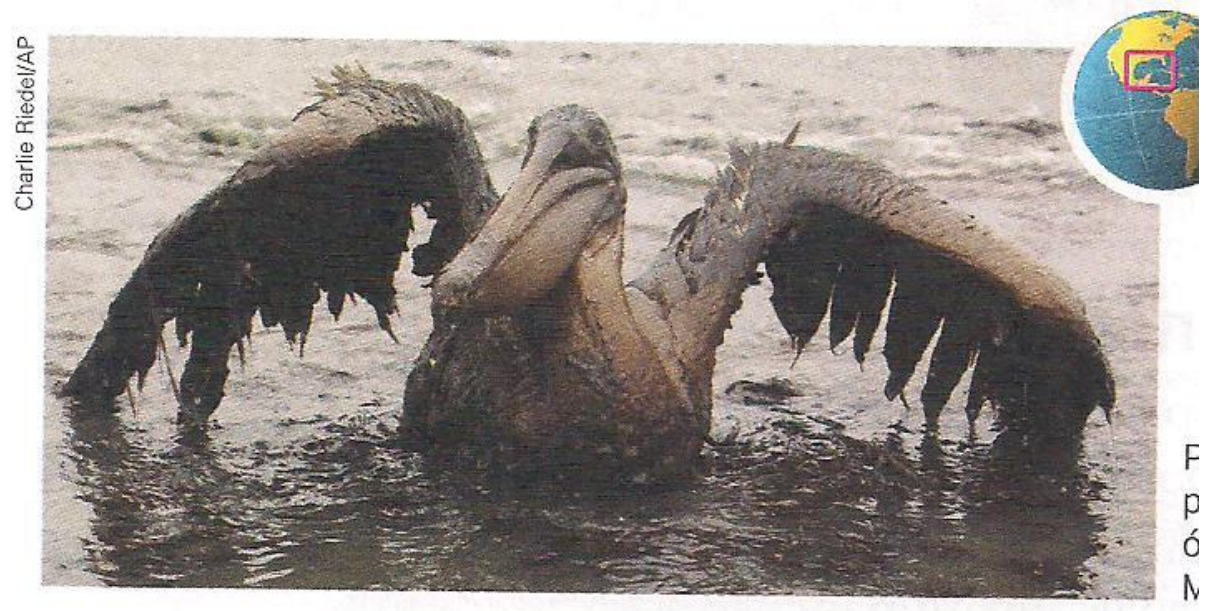

Figura 06. Pelicano atingido pelo vazamento de óleo no golfo do México, em 2010 Fonte: Sampaio, (2012, p.154).

O capítulo também chama a atenção para a relevância da água para a vida e a escassez de água potável, esclarecendo sobre o reuso do recurso por meio de uma atividade: Acesso à água tratada (FIGURA 07). A atividade, que propõe releitura e opinião própria, é interessante pelo fato de fazer o educando reler e expor o que imagina, facilitando o direcionamento da discussão pelo professor. Uma vez que parte do conhecimento prévio do aluno, do seu cotidiano, para se chegar à abstração já afirmada numa metáfora por Kaercher (2007, p. 31), "o professor fornece a escada para o aluno subir em abstração e conhecimento. Mas, logo, retira a escada e diz: - Vão descobrir outros caminhos". 


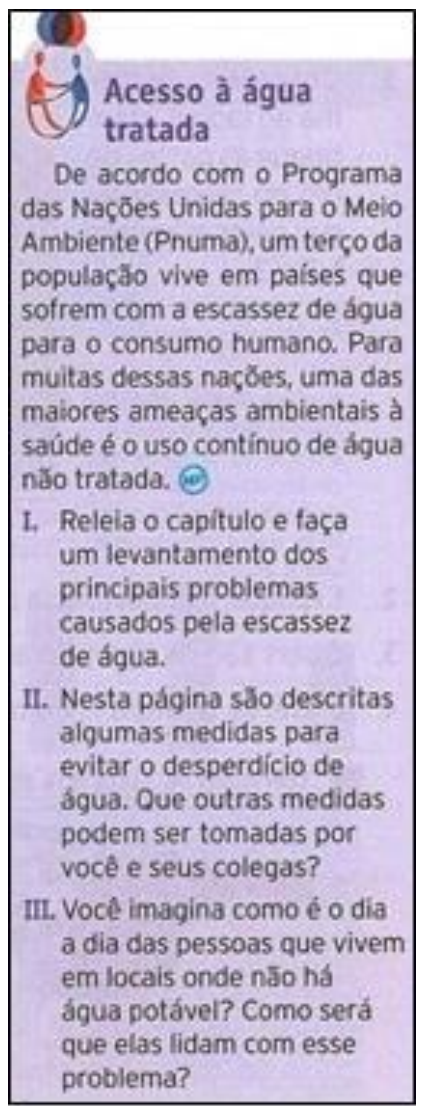

Figura 07. Atividades proposta de releitura e opinião dos alunos Fonte: Sampaio, (2012, p. 161).

Além do proposto no capítulo, sob o ponto de vista de aprendizagem e fixação, as atividades propostas (FIGURA 08) são interessantes porque propõem a utilização de vários recursos, tais como: produção de gráficos, perguntas, análise de textos e sugestões de livro e sites. Todos esses recursos despertam a análise e interpretação de texto, mas, para complementar a atividade, com o objetivo de valorizar o cotidiano dos alunos do município de Jataí. Sugere-se que os alunos levem para sala de aula o talão da conta de água emitido pela empresa responsável pelo abastecimento de água do município, com o demonstrativo do gasto de água mensal de cada residência, para que os alunos possam analisar o consumo e produzir um gráfico. Essa proposta pode ser executada em conjunto com outras disciplinas, como, por exemplo, a matemática. 


\section{Fazer e ler um gráfico de barras}

Um gráfico é uma representaçào que ajuda a estabelecer relaçós entre dados de um assunto. Uma forma bem simples de representaça é feita por graficos de barras. Neles, os diferentes tamanhos das barras representam os valores dos dados estudados.

Na tabela à direita (em cima) estăo os dados obtidos em um estudo sobre o consumo de Água nas atividades cotidianas em uma residència comum.

No graffico, a linha horizontal indica diferentes situaç̧es de uso da água.

As barras verticais representam o quan. to (em porcentagem) se gasta de água para a realizaça de cada atividade. Assim, quanto maior a quantidade de água usada para a realizaçaso de uma atividade, maior a altura da barra que a representa.

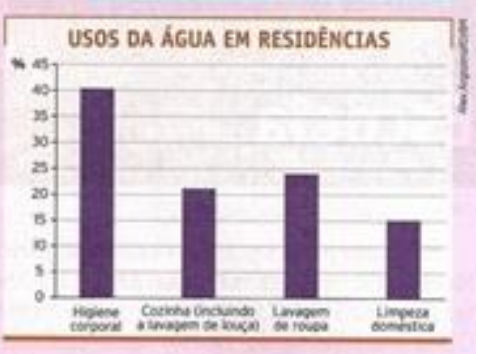

\section{Construindo}

Veja como construir o diagrama de barras

Para construir um graficico de burras, devemos seguir alguns passos,

1. Construa uma escala marcando o valor miximo ( $40 \%$ ) em uma linha vertical. Nesse exemplo, os valores da tabela aparecem em porcentagem, mas em outros casos podem aparecer como valores absolutos.

2. Se o valor muximo marcado no eixo vertical é de $40 \%$, a metade sera $20 \%$, e sua quarta parte sera $10 \%$. Seguindo esse criterio, represente todos os valores da tabela nessa escala.

3. Se preferir, para facilitar a visualizacho, trace linhas horizontais paralelas a partir da indicaça dos valores na escala.

4. Para cada um dos diferentes usos da a guras, constrôi-se uma barra com a altura corres. pondente ao dado da tabela e usando a escala lateral (de 0 a 45\%) como refertncia.

\section{- Atividades - meiposose sumere no cuberna}

1. Observe os dados da tabela abaixo. Eles representam a đistribuiç̧ăo do consumo de água no mundo, de acordo com a seguinte divisäo:

- Uso urbano: consumo doméstico e no setor de serviços urbanos (escolas, supermercados, limpeza de ruas, irrigaçăo de jardins, entre outros).

- Uso industrial: processos industriais.

- Uso agricola: irrigaçăo de lavouras, reservatórios de água para geraçăo de energia elétrica, entre outros.

a) Agora, tomando como base os dados da tabela ao lado, construa um grático de barras. linpost persoul $\Theta$

b) Analisando a distribuiçăo do consumo de água no mundo, crie hipóteses para

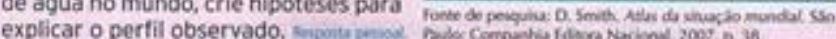

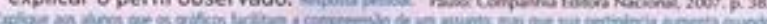

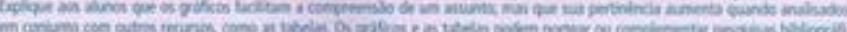

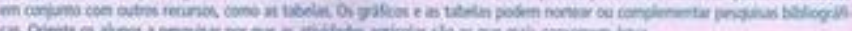

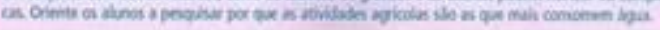

\begin{tabular}{|c|c|c|}
\hline Mngubeng & 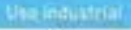 & 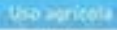 \\
\hline $9 \%$ & 1846 & $73 x$ \\
\hline
\end{tabular}


A poluição do ar foi apresentada através de um módulo intitulado Poluição atmosférica e suas consequências, inserido no Capítulo 7. Ela é retratada minunciosamente. Os fenômenos inversão térmica, destruição da camada de ozônio (Figura 9), efeito estufa, como evitar a contaminação atmosférica e o conceito de chuva ácida são explicados, retratados por Sampaio (2012, p. 188) no seguinte trecho:

No Brasil, a cidade de Cubatão, importante polo industrial no estado de São Paulo, apresentava altíssimos índices de poluição. Como consequência, a chuva destruiu áreas da mata Atlântica, próxima à cidade, e depois de muita pressão foi estabelecida uma legislação e rigorosa fiscalização para conter os gases poluentes em Cubatão.

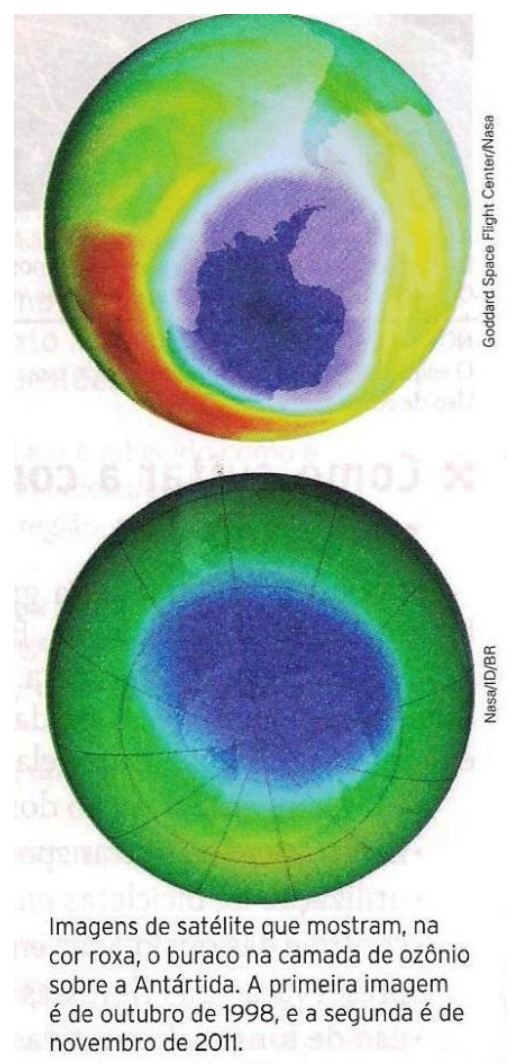

Figura 09. Imagem de satélite da camada de ozônio Fonte: Sampaio (2012, p.163). 
O livro consegue expressar uma visão ambiental nos alunos, mesmo não trabalhando os conteúdos propostos na pesquisa de forma conceitual. Porém, é possível que os educandos, a partir da visão passada na escola, possam interagir mais com a natureza, percebendo que não estamos isolados do contexto ambiental; mas que somos parte de um todo.

\section{Questões ambientais abordadas no livro didático Expedições geográficas, adotado pela rede estadual de Jataí}

Expedições geográficas, tem como autores Melhem Adas e Sérgio Adas. Assim como no livro da rede de ensino municipal, o tema educação ambiental não é discutido, apresentando somente as questões ambientais desmatamento, poluição da água, poluição do ar e mudanças climáticas, presentes na Unidade 8: Indústria, sociedade e espaço.

Sobre as mudanças climáticas, o livro dispõe de um pequeno parágrafo que enfoca os gases do efeito estufa da seguinte forma:

[...] não são apenas os automóveis, os caminhões e as queimadas os responsáveis pela emissão de gases capazes de provocar alterações climáticas. As atividades industriais realizadas em usinas termelétricas e em refinarias de petróleo, por exemplo, também lançam gases do efeito estufa, poluindo atmosfera (ADAS, M.; ADAS, S., 2011, p. 248).

O tema é abordado sem texto extra, exercício ou qualquer atividade que alerte os alunos sobre o tema, estimulando para a conscientização ambiental. São apresentados os climas do mundo e do Brasil, questionando sobre o tipo de clima no mundo. As ilustrações e mapas apresentam perguntas diretas que valorizam o lugar que os alunos vivem, trazendo o conteúdo para o cotidiano dos alunos, pois, observar o lugar daqueles que nele residem, ajuda-os a compreender o mundo. Cabe, portanto, ao professor, como mediador do conhecimento, aprofundar no assunto, utilizar outra fonte para pesquisa e elaborar alguma atividade.

A Unidade 08 apresenta as causas e consequências do desmatamento, advertindo sobre a retirada da vegetação, que afeta o retorno do vapor de água para a atmosfera, facilita a ocorrência de erosão do solo e coloca espécies animais e vegetais em risco de extinção.

Sobre a poluição do ar e da água, os autores retrataram a poluição no seu aspecto mais geral, citando a do solo, que afeta a água (FIGURA 10), descrevendo as suas causas e as consequências ao afirmarem que a "poluição do solo e das águas por detritos gerados pela indústria pode escoar com a água da chuva, infiltrar no solo e provocar a contaminação de lençóis de água subterrânea quando transportados pela enxurrada, poluindo rios e lagos". A poluição sonora também é citada, quando eles 
explicam que o ruído das máquinas das fábricas pode incomodar os vizinhos, e que quando ultrapassado o limite permitido, pode provocar danos ao aparelho auditivo.

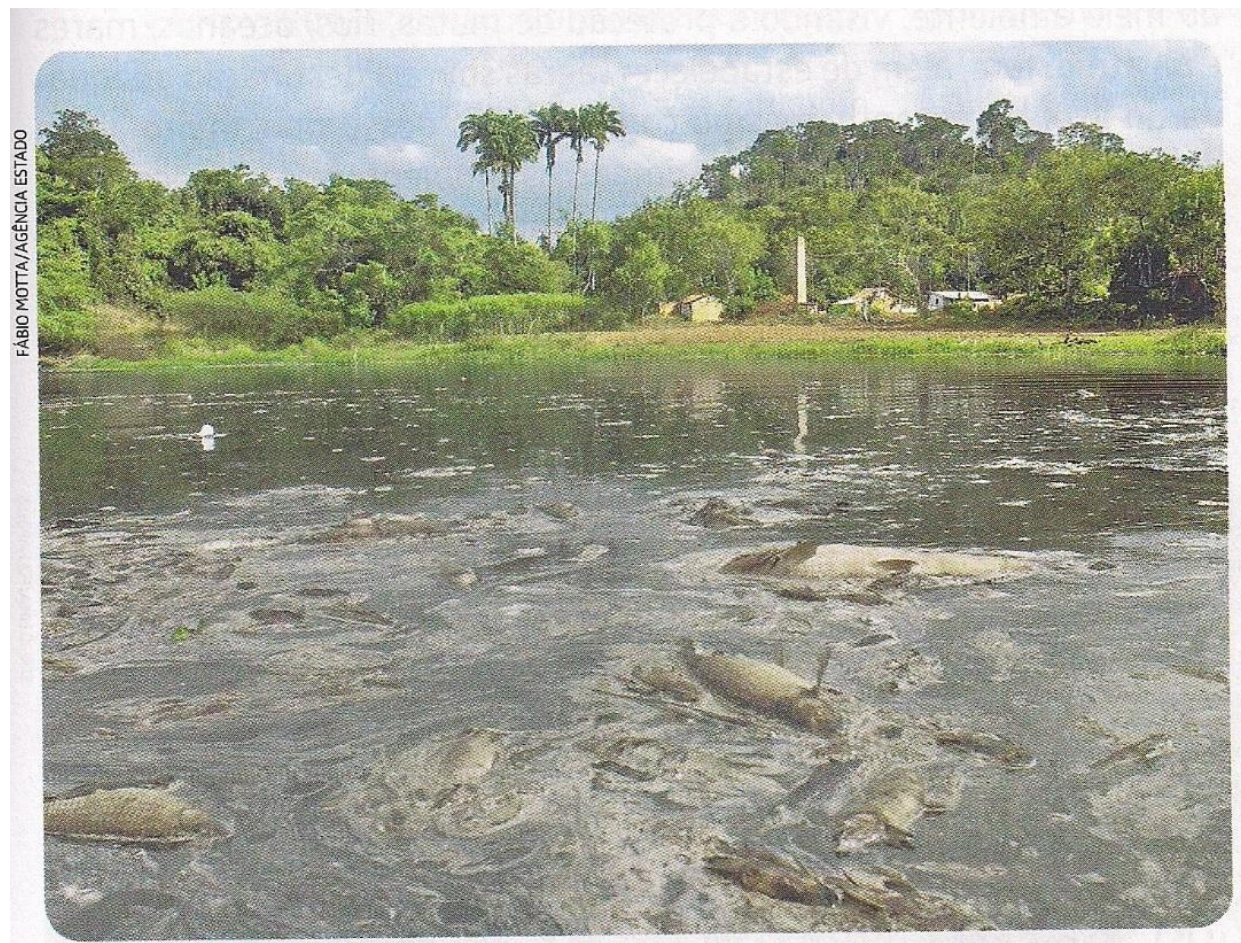

Figura 10. Poluição por produtos químicos lançados no rio Paraíba do Sul (RJ) Fonte: Adas, M. e Adas, S. (2011 p. 249).

No geral, Ada, M. e Ada, S. (2011) expõem os problemas ambientais de forma geral e superficial, e não se aprofundam nas questões do desmatamento, das mudanças climáticas e da poluição do ar e da água. Alguns problemas ambientais são tratados juntamente com o impacto ambiental e a indústria, sendo vinculados ao fortalecimento do trabalho assalariado e do capitalismo, à intensa urbanização, à divisão social do trabalho, às alterações do espaço geográfico, do poder econômico, financeiro e político, à indústria e aos impactos ambientais, à exploração dos recursos naturais e ao desmatamento, à poluição sonora, do solo e das águas.

Eles propõem duas atividades: uma sobre recursos naturais e outra sobre as fontes alternativas de energia. A primeira é o texto Energia: a ordem é economizar (FIGURA 11), que apresenta informações sobre o que se pode fazer para economizar os 


\section{recursos naturais e, no final do texto, são apresentados questionamentos sobre o tema para os alunos refletirem.}

\section{E stação Cidadania}

\section{Energia: a ordem é economizar}

Você faz parte do conjunto de pessoas que economizam energia elétrica e combustível? E seus familiares? Leia o texto a seguir e reflita, em grupo, sobre algumas ações que podem auxiliar a economizá-los.

\section{0 que você pode fazer?}

"[...]

- Regule a temperatura do chuveiro de acordo com as estações do ano e procure reduzir o tempo do banho.

- Se usar máquinas de lavar louças e roupas, ligue-as somente com toda a sua capacidade preenchida.

- Prefira lâmpadas fluorescentes. Elas consomem menos energia e duram mais que as comuns. Não se esqueça, porém, de que essas lâmpadas contêm substâncias químicas que podem ser prejudiciais à saúde se não forem descartadas adequadamente. $\mathrm{O}$ melhor é entregar nos locais de venda.

- Aproveite a iluminação natural e evite acender lâmpadas durante o dia.

- Apague a luz quando não houver ninguém no ambiente.

- Desligue a televisão quando não houver ninguém assistindo.
- Na hora de comprar eletrodomésticos, leve em conta a eficiência energética certificada pelo selo Procel (Programa Nacional de Conservação de Energia Elétrica) e dê preferência aos que utilizam gases inofensivos à camada de ozônio (livres de clorofluorcarbono, CFC).

- Ao comprar aquecedor, escolha um modelo com capacidade adequada às suas necessidades e leve em conta a possibilidade de uso da energia solar.

- Sempre que possível, utilize o transporte coletivo, preferencialmente o trem e o metrô. [...]

- Organize-se para reivindicar, junto ao poder público e às empresas, a implantação de políticas de controle da poluição, como melhorar o transporte coletivo, conservar áreas verdes e fiscalizar emissões de chaminés e veículos. [...]"

Instituto Brasileiro de Defesa do Consumidor (Idec). Energia: a ordem é economizar. Disponivel em: <www.idec.org.br>. Acesso em: 17 nov. 2011.

1. A redução do consumo de energia elétrica não se reflete apenas na diminuição da conta mensal, mas também na natureza. Explique de que maneira isso acontece.

2. No dia a dia, que atitudes podem ser tomadas por você ou por seus familiares para diminuir o consumo de energia elétrica e de combustível? Pense a respeito e troque ideias com seus colegas. Em seguida, elabore uma lista com as dicas para economizar esses recursos energéticos.

\section{Ambiente em casa de} campo com aproveitamento de iluminação natural em Visconde de Mauá, RJ (2007).

Figura 11. Atividade sobre recursos naturais

Fonte: Adas, M. e Adas, S. (2011 p. 251). 
Antes da atividade sobre fontes alternativas de energia, os autores apresentaram os tipos de fontes de energia renovável e não renovável e os impactos ambientais provocados durantes a instalação das usinas hidrelétricas (FIGURA 12). Além disso, alertam sobre as termelétricas, que são poluidoras por produzirem eletricidade através de queima de petróleo, carvão mineral, gás natural ou biomassa, lançando na atmosfera gases que comprometem a qualidade do ar e contribuem para intensificar o efeito estufa (ADAS, M.; ADAS, S., 2011).

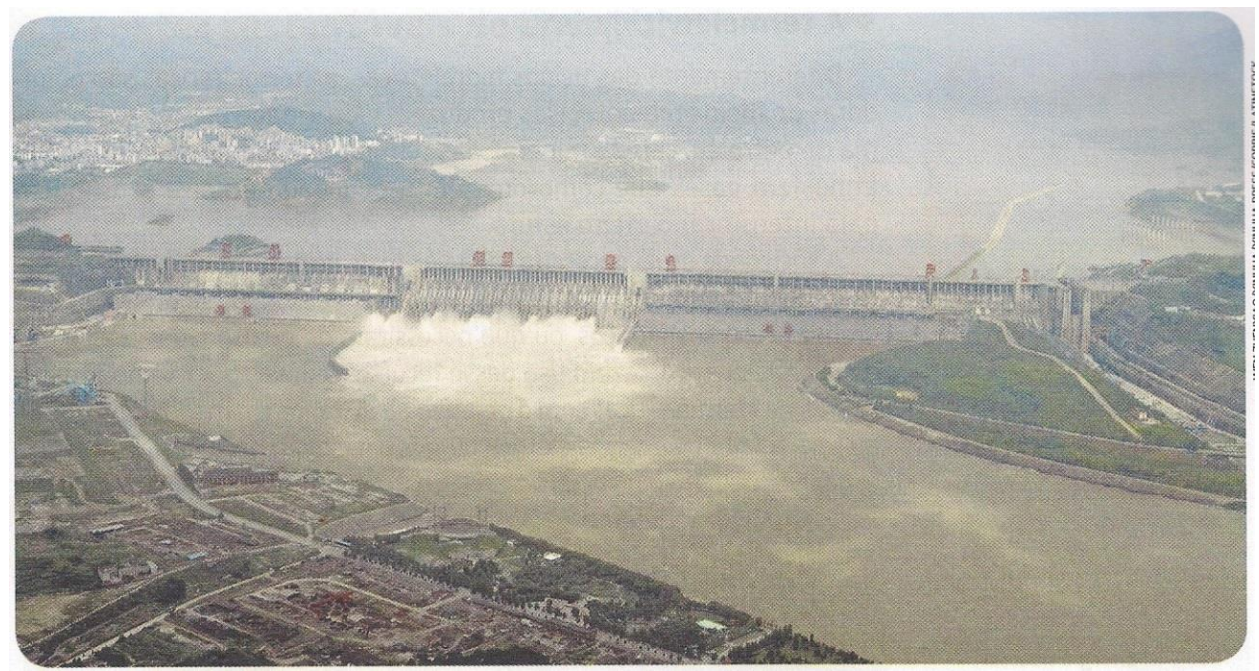

Figura 11. Atividade de pesquisa sobre fonte alternativa de energía.

Fonte: Adas, M. e Adas, S. (2011 p. 259).

Devido à existência de fontes de energia que poluem o ambiente, os autores incentivam a pesquisa de fontes alternativas de energia que não provoquem impactos ambientais e de informações sobre a produção mundial de energia eólica, por meio de duas perguntas. Sugerimos como atividade uma pesquisa sobre as hidrelétricas construídas na região Sudoeste de Goiás, questionando-se o motivo da construção e sua importância para o contexto nacional energético.

No livro da rede estadual de ensino, as questões ambientais são abordadas de forma superficial, com quantidade insuficiente de atividades, figuras, gráficos e textos contextualizados sobre os impactos ambientais e que estimulem a conscientização dos alunos. 


\section{Considerações finais}

Analisando o material didático adotado pelo município e pelo estado, notou-se que o livro didático é um material de apoio fundamental no desenvolvimento do trabalho docente e no processo de aprendizagem dos educandos. Por essa razão, as obras destinadas ao ensino e à aprendizagem da Geografia devem conter textos, atividades e ilustrações que possibilitem ao educando o domínio dos conceitos espaciais e da sua representação.

O ensino de Geografia possibilita aos alunos compreenderem a realidade social e a natureza, com destaque para as abordagens ambientais. $\mathrm{O}$ fundamental para a Geografia escolar é possibilitar ao aluno uma aprendizagem em que possa entender a localização dos lugares e a compreensão do que ocorre nos contextos local e global.

Em relação aos temas ambientais da pesquisa, ambos os livros analisados apresentaram os assuntos - mudanças climáticas, poluição do ar e da água, desmatamento - por meio de textos, ilustrações, pinturas, gráficos, mapas, fotografias, entre outros, o que estimula nos alunos um interesse e curiosidade para saber mais.

Para Viver Juntos, de Sampaio (2012), trabalha as questões ambientais de maneira mais questionadora, levando os alunos a refletirem sobre o tema trabalhado. Porém, o livro não consegue solucionar todos os questionamentos em alguns momentos, como nas questões da discussão do tema camada de ozônio e efeito estufa, ocasião em que o autor deixa de relatar dados da atualidade. Dessa forma, fica claro que é necessário sempre buscar novas fontes de pesquisa e atualizações. As lacunas encontradas podem ser solucionadas, visto que o livro didático é um norteador e não um produto final e acabado. Embora não haja a discussão sobre a EA, os demais conteúdos ambientais são trabalhados de forma mais consistente e propõem ao aluno uma reflexão sobre as problemáticas do ambiente.

No livro Expedições Geográficas, utilizado pelo Estado, as mudanças climáticas e a poluição do ar e da água são descritas vinculadas à indústria e aos impactos ambientais. Apesar do destaque para questões ambientais, o conteúdo é abordado de forma superficial, não há a conceituação de cada conteúdo.

Desta forma, os livros dão apoio para que o professor possa trabalhar suas aulas de forma interativa com os alunos, visando o aprendizado deles, levando-os a uma visão crítica das questões ambientais, considerando as sugestões dadas para abordá-las com maior aprofundamento. $\mathrm{O}$ conceito de educação ambiental não é discutido nos livros didáticos pesquisados, porém, os temas ambientais são trabalhados por meio de atividades, textos e climogramas. 


\section{Referências}

ADAS, S.; ADAS, M. Expedições geográficas. São Paulo: Moderna, 2011. 272 p.

BRASIL. Ministério da Educação. Guia de livros didáticos PNLD 2013 Geografia. Brasília: MEC, 2013. Disponível em:

<file:///C:/Dados\%20Usuario/Downloads/guia_pnld_2013_geografia.pdf>. Acesso em 13 abril 2015.

BRASIL. Ministério da Educação. Parâmetros curriculares nacionais: terceiro e quarto ciclos do ensino fundamental: introdução aos parâmetros curriculares nacionais. Brasília: MEC, 1998. Disponível em: <http://portal.mec.gov.br/seb/arquivos/pdf/introducao.pdf >. Acesso em: ago. 2018

CONAMA. Conselho Nacional do Meio Ambiente. Resolução CONAMA $n^{o}$ 003, de 28 de junho de 1990. Brasília, 1990. Disponível em:

<http://www.mma.gov.br/port/conama/res/res90/res0390.html>. Acesso em: 13 maio 2015.

DIAS, G. F. Educação: conhecendo o metabolismo da cidade. In: Educação ambiental: princípios e práticas. 9. ed. São Paulo: Gaia, 2004. p. 287-551.

DIAS, G. F. Subsídio para a prática de educação ambiental. In: Educação ambiental: princípios e práticas. 9. ed. São Paulo: Gaia, 2004. p. 209-233.

DESIDERIO, R de T. O ambiental nos livros didáticos de Geografia: uma leitura nos conteúdos de Geografia do Brasil. In: ENCONTRO DE GEOGRÁFOS DA AMÉRICA LATINA, 12., 2009, Montevideo. Anais... 2009. p. 1-13. Disponível em: <http://www.observatoriogeograficoamericalatina.org.mx/egal12/Ensenanzadelageografi a/Investigacionydesarrolloeducativo/31.pdf $>$. Acesso em: 10 maio 2015.

FARIA, W. R; HADDAD, E. A. Modelagem do uso da terra e mensuração dos efeitos de mudanças climáticas no Brasil. 2013. Disponível em: <http://www.usp.br/nereus/wpcontent/uploads/TD_Nereus_02_2013.pdf >. Acesso em 15 maio 2015.

FERREIRA, P. A. et al. O PCN de Geografia e a questão ambiental: uma análise a partir das referências bibliográficas do PCN de Geografia. Revista Geonorte. Edição Especial, v. 3 , n. 4 , p. 251-261, 2012.

FRISON. M. D. et al. Livro didático como instrumento de apoio para construção de propostas de ensino de ciências naturais. In: ENCONTRO NACIONAL DE PESQUISA DE EDUCAÇÃO EM CIÊNCIAS, 7., 2009, Florianópolis, Anais... 2009. Disponível em: <http://posgrad.fae.ufmg.br/posgrad/viienpec/pdfs/425.pdf>. Acesso em: 25 ago. 2014. 
IBAMA. Instituto Brasileiro do Meio Ambiente e dos Recursos Naturais. Áreas temática/Desmatamento. Disponível em: <http://www.ibama.gov.br/areastematicas/desmatamento>. Acesso em: 13 maio 2015.

IBGE. Instituto Brasileiro de Geografia e Estatística. Cidades. 2010. Disponível em: $<$ http://www.cidades.ibge.gov.br/xtras/perfil.php?lang=\&codmun=521190\&search=goia sjjatai>. Acesso em: 14 out. 2013.

KAERCHER, N. A. A Geografia escolar: gigante de pés de barro comendo pastel de vento num fast food? Terra Livre, ano 23, v. 1, n. 28, p. 27-44, 2007. Disponível em: 〈http://www.educadores.diaadia.pr.gov.br/arquivos/File/deb_nre/geografia.pdf>. Acesso em: 09 set. 2014.

LAKATOS, E.; MARCONI, M. de A. Técnicas de pesquisa. São Paulo: Editora Atlas, 2002. Disponível em: <https://www.passeidireto.com/arquivo/3680409/tecnicas-depesquisa---marconi-lakatos〉. Acesso em: 16 abr. 2015.

PINTO, A. P. O lixo e sua história em Jataí. 2007. 69 f. Trabalho de Conclusão de Curso (Monografia) - Universidade Federal de Goiás, Goiânia, 2007.

PINTO, A. P. Questões Ambientais No Ensino De Geografia Nas Escolas Públicas Em Jataí. 2015. 107 f. Dissertação (Mestrado) - Programa de Pós-Graduação em Geografia, Universidade Federal de Goiás, Regional Jataí, Jataí, 2015.

REIGOTA, M. O que é educação ambiental. São Paulo: Brasiliense, 2006.

REGO, F. C. R, et al. O que é lixo afinal? Como pensam mulheres residentes em uma periferia de um grande centro urbano. Cadernos de Saúde Pública, v. 18, n. 6, 2002.

SAMPAIO, F. dos S. Para viver juntos: Geografia. 3. ed. São Paulo: SM. 70 p.

SILVA, D. L. M. da. A Geografia que se ensina e a abordagem da natureza nos livros didáticos. 2004. 104 f. Tese (Doutorado) - Programa de Pós Graduação em Geografia, Universidade Federal do Rio Grande do Sul, Porto Alegre, 2004.

SPOSITO, E. S. O livro didático de Geografia: necessidade ou dependência? Análise da avaliação das coleções didáticas para o ensino fundamental. In: SPOSITO, M. E. B. (Org.). Livros didáticos de História e Geografia: avaliação e pesquisa. São Paulo: Fundação Editora da UNESP, 2006. p.26.

\footnotetext{
Andréa Pereira Pinto

Mestra em Geografia pela Universidade Federal de Goiás, Regional Jataí-GO. Graduada em Geografia e Especialista em Gestão e Educação Ambiental pela mesma instituição. Atualmente é professora de ensino fundamental II e médio no Colégio Nossa Senhora do Bom Conselho e Colégio Cesut/Anglo, em Jataí-GO.

Endereço: Av. Rio Claro, 876, setor Central, Jataí-GO, CEP: 75.800-063.

E-mail: andreageog@hotmail.com
} 


\section{Zilda de Fátima Mariano}

Doutora em Geografia pela Universidade Estadual Paulista, Campus de Rio Claro. Mestra em Agronomia/ESALQ/USP. Graduada (Licenciatura e Bacharelado em Geografia) e Especialista em Gestão Municipal pela mesma instituição. Foi professora do curso de Geografia (Licenciatura e Bacharelado) e da Pós-Graduação em Geografia (Mestrado e Doutorado) na Universidade Federal de Goiás, Regional Jataí-GO.

Endereço: UFG - Unidade Riachuelo. R. Riachuelo, 1530 - Setor Samuel Graham, Jataí - GO, 75804-020

E-mail: zildadefatimamariano@gmail.com

Recebido para publicação em janeiro de 2016. Aprovado para publicação em outubro de 2016. 